\title{
The Drivers of Firms' Environmental Management: Soft Environmental Management vs. Hard Environmental Management
}

\author{
Yuan Ma*, Jingzhi Men \\ College of Economics and Management, Shandong University of Science and Technology, Qingdao, P.R. China
}

Received: 9 February 2021

Accepted: 2 July 2021

\begin{abstract}
Environmental management is an effective approach to realize sustainable development. Environmental management is divided into two dimensions, soft environmental management and hard environmental management in this article and the drivers of these two dimensions are analyzed. 211 valid survey data from manufacturing firms are used to test the hypotheses. It is found that regulatory pressure, market pressure, slack resources and top management's environmental awareness have positive effects on both soft environmental management and hard environmental management. Furthermore, soft environmental management is more susceptible to be affected by external pressures of government and market, while hard environmental management is more likely to be driven by internal pressures of slack resources and top management's environmental awareness.
\end{abstract}

Keywords: environmental management, regulatory pressure, market pressure, slack resources, top management's environmental awareness

\section{Introduction}

The increasingly severe global environmental crisis has put forward the requirements for sustainable development worldwide. How to achieve the coordinated development of economic growth and environmental protection has become an important issue nowadays. At the same time, environmental management (EM) has become a relatively optimal option for firms as a method to obtain competitive advantage and achieve sustainable development under such ever-growing environmental pressures [1]. However, the remarkable

*e-mail: may@sdust.edu.cn peculiarity of EM, referred to as "double externality", cannot realize Pareto efficiency, which inevitably leads to insufficient motivations for firms. To further complicate the situation, the knowledge remains unclear on what the driving forces of EM are, which calls for a further investigation into the interaction between EM and its drivers.

How to drive firms to adopt EM practices is a central argument in the field of environmental science. The previous research mainly explores the factors affecting EM practices with consideration of the external and internal conditions. The research perspective of external contexts has mainly been based on institutional theory and stakeholder theory $[2,3]$. Researches applying institutional theory suggest 
all the institutional pressures (coercive pressure, normative pressure and mimetic pressure) can influence firms' responses to environmental issues through legitimacy [2]. Studies in the field of stakeholder theory emphasize the role of stakeholders because they exert pressures on firms with the aim of reducing negative or improving positive environmental impacts [4]. It has also been indicated that pressures from different stakeholders are identified as determinants for firms' EM practices such as regulators [1], suppliers [4], and consumers [5].

EM is dependent on the capabilities and resources within a firm. From an internal perspective, the weakness of a firm's capabilities and its shortage in resources may be major impediments for firms' environmental activities based on the resource-based view [6]. As an indispensable strategic capability, top management's environmental awareness can influence individuals and foster firms to identify and achieve corporate sustainability visions [7]. In addition, available resources empower firms to be more capable of obtaining the necessary material and human talent to launch EM practices [8].

These researches have achieved mountains of valuable results, while some deficiencies on the driving forces of EM practices still exist. First, previous studies have paid more attention to the direct effect of each independent variables on EM practices while a careful consideration of internal and external factors is lacking [7]. Second, most of the existing studies explore the EM drivers from a holistic perspective ignoring consideration of the heterogeneity of EM practices [4]. What is also missing in extant literature is an analysis of how those drivers differ for different aspects of EM. It is highly likely that different dimensions of EM are driven by different factors [9]. Following this vein, this study divides EM into soft environmental management (SEM) and hard environmental management (HEM), based on which, following questions can be addressed: do external drivers (regulatory pressure and market pressure) and internal drivers (slack resources and top management's environmental awareness) trigger the implementation of SEM and HEM? If so, which type of driver is the most effective to advance SEM and HEM, respectively?

By answering the above research questions, two contributions are provided to the current literature. First, a distinction of SEM and HEM is made. This classification improves the pertinence of extant research. In particular, the two dimensions of EM help to explain the heterogeneity of EM practices and to focus the managers' attention on specific aspects of EM. Second, this study helps better explore the specific driving factors of heterogeneous EM practices. Correctly understanding the drivers of SEM and HEM is conducive to design and formulate effective policies for researchers and decision-makers.

The remainder of this paper is structured as follows. Literature review is conducted and hypotheses are formulated in Section 2. The methods and sample data are described in section 3 . The research findings and discussions are presented in section 4, closely followed by section 5 for concluding remarks and implications.

\section{Theories and Hypotheses}

\section{Definition of Concepts}

EM practices should be viewed as a continuous process of improving environmental policies and programs to reduce firm's environmental impact. It is devoted to minimizing the negative environmental impact of firm's products and services [10]. Such practices including: (1) collection and disclosure of environmental information; (2) development of environmental solutions; (3) settlement for environmental problems; (4) implementation of employee training [11, 12]. Scholars generally believe that EM and quality management have a lot in common $[12,13]$. Inspired by the research in quality management domain [14], this article classifies EM practices into two dimensions, soft environmental management (SEM) and hard environmental management (HEM).

SEM refers to management principles or environmental policies that firms take for environmental improvements, such as environmental information collection, environmental information disclosure, employee training, and employee participation [10, 15]. It plays a supportive role. HEM emphasizes the environmental practices relating to technology and outcome, such as green product design, green manufacturing process adoption, and statistical control/ feedback with the characteristics of being technological and being structural [16]. It plays a substantial role in firms' EM [17].

\section{External Drivers of EM}

\section{Regulatory Pressure}

Regulatory pressures are typically exerted by powerful groups (e.g., government agencies) aiming to protect the environment and to pursue sustainable development [8], who have been the most effective drivers for EM practices adoption [18]. The mechanism in generating impetus upon firms is not just the presence of regulations per se but also the capacity of government to monitor firms' behavior and enforce these regulations when necessary [19]. In practice, imposition and inducement mechanisms are effective approaches to affect firms to adopt environmental activities [2]. On the one hand, these regulations have established standards for products, manufacturing processes and the disposal of waste materials [20]. If firms fail to accord with these mandatory standards 
and restrictions, they will be expelled from the market. On the other hand, inducement mechanism can entice firms to behave environmentally through the use of more positive incentives and rewards [19]. If firms' actions can conform with these incentive regulations and standards, they will gain government supports, such as subsidy, open-ended contracts, favorable tax laws, or tradeable permits [2]. Therefore, faced with the risks of unconformity with mandatory regulations and the opportunities of conformity with incentive regulations, firms are more inclined to implement EM practices. This leads to the following hypotheses:

- H1a: Regulatory pressure poses a positive impact on SEM.

- H1b: Regulatory pressure poses a positive impact on HEM.

\section{Market Pressure}

Market factors form the core normative pressure for firms' environmental initiatives [20]. It is essential for firms to maintain contact with market participants who formulate relevant behaviors, norms, and standards for firms during the business. These sorts of environmental norms and standards may affect the degree to which firms operate in pro-environmental ways since they are associated with the issue of legitimacy [8]. To quest the legitimacy, firms will endeavor to operate in accordance with market expectations [8]. Such proactive practices as collecting environmental information from their target customers for designing and manufacturing environmentally friendly product [21], disclosing environmental information to stakeholders [17], and providing employee training to solve environmental issues [22], through which they can obtain not only external legitimacy, but also competitive advantage and green brand recognition [17]. Conversely, firms will suffer resistance, isolation, and market protest if they violate these environmental norms and standards [23]. Hence, we hypothesize:

- H2a: Market pressure poses a positive impact on SEM.

- H2b: Market pressure poses a positive impact on HEM.

\section{Internal Drivers of EM}

\section{Slack Resources}

Slack resources are actual or potential resources that enable organizations to successfully accommodate internal and external uncertainties [24]. From the perspective of Resource Based View, firms will outperform their rivals and then receive competitive advantages due to the rare, irreplaceable, valuable, and inimitable resources [8]. Most importantly, firm's strategies and actions are dependent on, and even constrained by a firm's resource profiles [8].
The lack of sufficient resources may hinder the implementation of environmental initiatives, since firms with little slack must use their scarce resources to its most immediate and pressing needs while neglecting environmental demand [8]. By contrast, sufficient resources are important inputs to the design and implementation of sound environmental practices as they help firms bear the costs of implementing such eco-friendly initiatives [25], buffer the uncertainty of taking risky initiatives in response to external pressure, provide the technological and human basis for sustainable development [26], and enrich strategic choices thereby enhancing the flexibility and adaptability to external changes [8]. That is to say, ample slack resources can motivate firms more likely to engage in environmentally friendly behaviors. This leads to the following hypotheses:

- H3a: Slack resources pose a positive impact on SEM.

- H3b: Slack resources pose a positive impact on HEM.

\section{Top Management's Environmental Awareness}

Differences of top management determine the heterogeneity in the strategic decisions and actions of each company based on the Upper Echelon Theory [27]. This logic is also applicable in the context of firms' adoption of EM practices. Top management's attitudes on environmental issues affect firm's environmental behaviors [28]. Those top managements who are highly committed to environmental protection may regard such eco-practices as corporate social responsibility and will broader and more deeply engage in green initiatives [29]. Consequently, environmental awareness of top management is driving firms to implement EM practices, such as disclosing environmental information which is conducive to assume social responsibility and maintain good relationships with stakeholders, providing training programs related to environmental protection and encouraging all employees to engage in EM practices [17]. Furthermore, researchers have also reported that pro-environmental top management will provide timely and adequate resources to environmentally benign product and process to minimize negative environmental impacts [23]. Hence, we hypothesize:

- H4a: Top management's environmental awareness influences SEM positively.

- H4b: Top management's environmental awareness influences HEM positively.

\section{Comparison of External and Internal Drivers}

SEM, such as environmental information collection, environmental information disclosure, employee participation and employee training, tends to be social and non-technical [10]. Complying with the norms of 
government and regulatory agencies, and meeting the requirements of specific stakeholders to obtain legitimacy is the main purpose of environmental information disclosure [17, 30]. Information collection more or less relies on the help of external organizations such as government for it provides firms with information in the context of which customer demand is vague [18]. In addition, the extent of green training and employee engagement in sustainability-oriented practices seemingly relate to government support and market context, with government funding for such training and market resisting environmentally unfriendly behaviors [23]. Therefore, the social-oriented characteristics of SEM make it more vulnerable to be influenced by external drivers.

HEM focuses on environmental measures concerning process and technology, such as green product design, green manufacturing process and statistical control/ feedback, following a structural problem-solving model to generate solutions for working smoothly [31]. As a substantial environmental management tool, HEM employs systematic and prospective technology to design green product, and improve the efficiency of green process by identifying and repairing defects timely. This sort of "hard" measures requires long-term investments on technologies, human resources, and so forth, reflecting the significant role of top management's green awareness and abundant resources within firms as environmentally conscious top management will schedule resources preferentially to environmentally benign projects $[23,32]$. Therefore, it can be seen that the technical and outcome-oriented characteristics of HEM make it more susceptible to be affected by internal factors. This leads to the following hypotheses:

- H5a: Compared with internal drivers, external drivers have a greater impact on SEM.

- H5b: Compared with external drivers, internal drivers have a greater impact on HEM.

\section{Material and Methods}

\section{Sample and Data}

The study collected data from manufacturing firms in Shandong Province, China. China has reaped remarkable economic growth over the past three decades, yet serious environmental pollution has been caused due to the traditional "get rich first and clean up later" mindset [33]. However, Chinese government began to focus on issues related to environmental protection, resource conservation, and climate change since the $11^{\text {th }}$ Five Year Plan (2006-2010). Shandong is a province in the east coastal area of China, ranking third in terms of economic development of all provinces. It is going through a transition with traditional drivers being replaced by new ones and puts forward stricter requirements of cleaner production to manufacturing firms, such as the implementation of energy efficiency labeling and energy-saving product certification systems [34]. Therefore, in this study, manufacturing industry in Shandong province is suitable as the subject of investigation.

Questionnaires were used to collect data. The questionnaire was mainly completed by firm's general manager, environmental department manager or other department managers with relevant environmental knowledge. 400 questionnaires were distributed and 237 were recovered, with a recovery rate of $59.25 \%$. After removing incomplete questionnaires such as missing items and conflicting answers, 211 valid questionnaires were retained, with the effective rate of $52.75 \%$. SPSS24.0 software is used to analyze the sample data. The specific characteristics of the samples are shown in Table 1.

\section{Measures}

Five-point Likert scale is used to test the multiitem constructs of the research questions, ranging

Table 1. The distribution of samples.

\begin{tabular}{|c|c|c|c|c|c|c|c|}
\hline & \multicolumn{3}{|c|}{ The characteristics of respondents } & & \multicolumn{3}{|c|}{ The characteristics of sample firms } \\
\hline & Item & Number & Percentage & & Item & Number & Percentage \\
\hline \multirow{2}{*}{ Gender } & Male & 114 & $54.0 \%$ & \multirow{3}{*}{ Firm age } & $<5$ & 73 & $34.6 \%$ \\
\hline & Female & 97 & $46.0 \%$ & & $5-10$ & 67 & $31.8 \%$ \\
\hline \multirow{4}{*}{ Age } & $<30$ & 57 & $27.0 \%$ & & $>10$ & 71 & $33.6 \%$ \\
\hline & $30-40$ & 69 & $33.0 \%$ & \multirow{3}{*}{ Firm size } & $<300$ & 68 & $32.0 \%$ \\
\hline & $41-50$ & 56 & $27.0 \%$ & & $300-1000$ & 109 & $52.0 \%$ \\
\hline & $>50$ & 29 & $14.0 \%$ & & $>1000$ & 34 & $16.0 \%$ \\
\hline \multirow{3}{*}{ Position } & Senior & 37 & $17.5 \%$ & \multirow{3}{*}{ Ownership } & State-owned & 64 & $30.3 \%$ \\
\hline & Middle & 65 & $30.8 \%$ & & Private & 94 & $44.5 \%$ \\
\hline & Primary & 109 & $51.7 \%$ & & Foreign-investment & 53 & $25.1 \%$ \\
\hline
\end{tabular}


from 1 ("strongly disagree") to 5 ("strongly agree"). The specific descriptions of multiple items are presented in Appendix 1.

\section{Independent Variables}

Regulatory pressure. Three items are used to measure this variable [20, 23]. Sample items include "Our production activities should be in accord with the requirements of national environmental regulations", "Our green production can be subsidized by the government".

Market pressure. Four items are used to measure this variable [23], for example, "Our customers often consider environmental factors when making purchase choices".

Slack resources. Three items are used [23, 35]. Example items include "Our firm is equipped with sufficient physical resources for pro-environmental practices" and "Our firm is equipped with ample financial resources for pro-environmental practices".

Top management's environmental awareness. Three items are used [12, 36], sample items include "Our top management can obtain valuable information to improve the environmental performance" and "Our top management spend enough time identifying environmental defects in firm's operations".

\section{Dependent Variables}

SEM: Based on the researches of Flynn, Schroeder and Sakakibara [16] and Tung, Baird and Schoch [12], seven items are used to measure SEM. Example items include "Adequate training in environmental preservation has been provided to employees", “Employees' environmental suggestions are treated as important references to improve environmental performance" and "Customer requirements are taken into account and comprehensively analyzed in our production".

HEM: Six items are drawn from the researches of Zhu and Sarkis [37] and Flynn, Schroeder and Sakakibara [16] to assess HEM, sample items include
"Our products are designed to minimize material/ energy consumption", "Employees are provided with available information of raw material consumption and waste discharge" and "Manufacturing process will be stopped immediately for environmental problems".

\section{Control Variables}

Firm size is measured by firm's number of employees, and a logarithm transformation is performed.

Firm age is computed by the total number of years a firm exists, and a natural logarithm transformation is applied.

Ownership. Firms are categorized into 3 types, stateowned, private and foreign investment, and construct dummy variables related to firm ownership type.

\section{Results and Discussion}

\section{Descriptive Statistics and Correlation Analysis}

Descriptive statistics and Pearson correlation coefficients of variables are shown in Table 2. The variance inflation factor (VIF) is less than 2 , indicating that multicollinearity does not inhibit our findings. It can be seen from the results that both the SEM and HEM are significantly related to regulatory pressure, market pressure, slack resources, and top management's environmental awareness. It is also demonstrated that the mean of SEM exceeds HEM's, indicating that HEM is implemented to a lesser extent than SEM.

\section{Reliability and Validity Analysis}

This study employs SPSS 24.0 to analyze the reliability and validity of the scales. The reliability of the variables is assessed using Cronbach's alpha and composite reliability. As indicated in Table 3, Cronbach's alpha and composite reliability of all the variables are greater than 0.60 , indicating the reliability of the variables [38].

Table 2. Descriptive statistics and correlations among variables.

\begin{tabular}{|c|c|c|c|c|c|c|c|c|}
\hline Variables & MEAN & S.D. & RP & MP & SR & TMEA & SEM & HEM \\
\hline RP & 3.213 & 1.366 & 1 & - & - & - & - & - \\
\hline MP & 3.475 & 1.300 & $.421^{* *}$ & 1 & - & - & - & - \\
\hline SR & 3.272 & 1.214 & $.321^{* *}$ & $.385^{* *}$ & 1 & - & - & - \\
\hline TMEA & 3.106 & 1.429 & $.243^{* *}$ & $.225^{* *}$ & $.186^{*}$ & 1 & - & - \\
\hline SEM & 3.906 & 0.972 & $.490^{* *}$ & $.563^{* *}$ & $.486^{* *}$ & $.405^{* *}$ & 1 & - \\
\hline HEM & 3.220 & 1.376 & $.452^{* *}$ & $.421^{* *}$ & $.409^{* *}$ & $.452^{* *}$ & $.488^{* *}$ & 1 \\
\hline
\end{tabular}

${ }^{* * *}$ significant at $.001 ;{ }^{* *}$ significant at $.01 ;{ }^{*}$ significant at $.05 ; \mathrm{RP}=$ regulatory pressure; $\mathrm{MP}=$ market pressure; $\mathrm{SR}=$ slack resources; TMEA = top management's environmental awareness; SEM = soft environmental management; HEM = hard environmental management. 
Table 3. Reliability and validity analysis.

\begin{tabular}{|c|c|c|c|c|}
\hline Constructs & Item code & Factor loading & Cronbach's $\alpha$ & Composite reliability \\
\hline \multirow{3}{*}{ Regulatory Pressure } & RP1 & 0.747 & \multirow{3}{*}{0.895} & \multirow{3}{*}{0.664} \\
\hline & RP2 & 0.554 & & \\
\hline & RP3 & 0.582 & & \\
\hline \multirow{4}{*}{ Market Pressure } & MP1 & 0.809 & \multirow{4}{*}{0.967} & \multirow{4}{*}{0.887} \\
\hline & MP2 & 0.802 & & \\
\hline & MP3 & 0.844 & & \\
\hline & MP4 & 0.801 & & \\
\hline \multirow{3}{*}{ Slack Resources } & SR1 & 0.615 & \multirow{3}{*}{0.912} & \multirow{3}{*}{0.634} \\
\hline & SR2 & 0.603 & & \\
\hline & SR3 & 0.596 & & \\
\hline \multirow{3}{*}{ Top Management's Environmental Awareness } & TMEA1 & 0.814 & \multirow{3}{*}{0.961} & \multirow{3}{*}{0.862} \\
\hline & TMEA2 & 0.812 & & \\
\hline & TMEA3 & 0.840 & & \\
\hline \multirow{7}{*}{$\begin{array}{l}\text { Soft Environmental } \\
\text { Management }\end{array}$} & SEM1 & 0.671 & \multirow{7}{*}{0.925} & \multirow{7}{*}{0.869} \\
\hline & SEM2 & 0.702 & & \\
\hline & SEM3 & 0.696 & & \\
\hline & SEM4 & 0.688 & & \\
\hline & SEM5 & 0.694 & & \\
\hline & SEM6 & 0.711 & & \\
\hline & SEM7 & 0.715 & & \\
\hline \multirow{6}{*}{ Hard Environmental Management } & HEM1 & 0.868 & \multirow{6}{*}{0.976} & \multirow{6}{*}{0.934} \\
\hline & HEM2 & 0.860 & & \\
\hline & HEM3 & 0.772 & & \\
\hline & HEM4 & 0.865 & & \\
\hline & HEM5 & 0.840 & & \\
\hline & HEM6 & 0.819 & & \\
\hline
\end{tabular}

The content validity of the survey is supported by relevant theoretical literature. The convergent validity of the scale is evaluated by factor loading and scale reliability. As shown in Table 3, all items exceed the threshold value of 0.50 , indicating good convergent validity [39].

\section{Regression Results}

In order to further verify the research hypotheses, hierarchical regression analysis is performed, and the results are shown in Table 4.

The dependent variables of Model 1 and Model 2 are SEM. Control variables are included in Model 1. The main four independent variables are added in Model 2. The results show that the coefficients of the four independent variables are positive, and all four of these variables are highly significant (at the $0.1 \%$ level), indicating that regulatory pressure, market pressure, slack resources, and top management's environmental awareness positively affect SEM. Therefore, hypotheses 1a, 2a, 3a and 4a are supported.

The dependent variables of Model 4 and Model 5 are HEM. Control variables are added in Model 4, and four independent variables are added in Model 5. The results clearly state that the coefficients of the four independent variables are positive, and highly significant (at the $1 \%$ level), implying that HEM is positively affected by regulatory pressure, market pressure, slack resources, and top management's environmental awareness. Therefore, hypotheses $1 \mathrm{~b}, 2 \mathrm{~b}, 3 \mathrm{~b}, 4 \mathrm{~b}$ are supported.

Regulatory pressure and market pressure are integrated into external drivers, and slack resources and top management's environmental awareness into 
Table 4. Regression results.

\begin{tabular}{|c|c|c|c|c|c|c|}
\hline \multirow{2}{*}{ Variables } & \multicolumn{3}{|c|}{ SEM } & \multicolumn{3}{|c|}{ HEM } \\
\hline & M1 & M2 & M3 & M4 & M5 & M6 \\
\hline Firm age & .057 & .024 & .025 & .030 & -.001 & -.002 \\
\hline Firm size & -.001 & -.065 & -.066 & .152 & .087 & .091 \\
\hline Firm ownership & -.017 & .016 & .014 & -.058 & -.041 & -.037 \\
\hline $\mathrm{RP}$ & & $.221^{* * *}$ & & & $.231^{* * *}$ & \\
\hline MP & & $.324^{* * *}$ & & & $.170^{* *}$ & \\
\hline SR & & $.249^{* * *}$ & & & $.207^{* *}$ & \\
\hline TMEA & & $.237^{* * *}$ & & & $.312^{* * *}$ & \\
\hline External drivers & & & $.468^{* * *}$ & & & $.327^{* * *}$ \\
\hline Internal drivers & & & $.370^{* * *}$ & & & $.405^{* * *}$ \\
\hline $\mathrm{R}^{2}$ & .004 & .509 & .507 & .026 & .416 & .410 \\
\hline$\Delta \mathrm{R}^{2}$ & .004 & .505 & .507 & .026 & .389 & .410 \\
\hline $\mathrm{F}$ & .248 & $30.013^{* * *}$ & $42.174^{* * *}$ & 1.864 & $20.628^{* * *}$ & $28.533^{* * *}$ \\
\hline
\end{tabular}

${ }^{* * *}$ significant at $.001 ;{ }^{* *}$ significant at $.01 ;{ }^{*}$ significant at $.05 ; \mathrm{SEM}=$ soft environmental management; HEM = hard environmental management; $\mathrm{RP}=$ regulatory pressure; $\mathrm{MP}$ = market pressure; $\mathrm{SR}=$ slack resources; TMEA = top management's environmental awareness

internal drivers to further test hypotheses $5 \mathrm{a}$ and $5 \mathrm{~b}$. The dependent variable in Model 3 is SEM, and the regression results show that external drivers $(\beta=0.468$, $\mathrm{P}<0.001)$ has a greater effect on SEM compared with internal drivers $(\beta=0.370, \mathrm{P}<0.001)$. The dependent variable in Model 6 is HEM, and the results state that the predictive effect of internal drivers $(\beta=0.405$, $\mathrm{P}<0.001)$ is higher than external drivers $(\beta=0.327$, $\mathrm{P}<0.001$ ). In order to examine the significance of this regression result, this article employs Bootstrap's method to randomly sample 5000 times to verify the confidence interval (CI) of coefficient difference (internal drivers minus external drivers). As for HEM, if the $\mathrm{CI}$ is on the right side of 0 , it proves that internal drivers are more significant, but for SEM, if the CI is on the left side of 0 , it explains that external drivers impose a more significant role. The results demonstrate that the CI of HEM is [0.111, 0.219], and the CI of SEM is $[-0.483,-0.181]$, at $95 \%$ confidential level, so both of the results are significant. Hypotheses $5 \mathrm{a}$ and $5 \mathrm{~b}$ are supported.

\section{Discussion}

The result shows the mean of SEM exceeds HEM's, illustrating that SEM is much easier to apply within the firms. The possible explanations for this phenomenon may be as follows. The management methods involved in SEM are universal, easier to be imitated, and lower in cost, while a tremendous amount of time and money need to be put in HEM because it mainly relates to the improvements of product and process, and closely integrates with firm-specific technology and resources.
Regulatory pressure has a positive relationship with SEM and HEM. Government usually employs enforced legislations and regulations to control firms' manufacturing input (e.g., requiring usage of recycle materials), process (e.g., adopting green manufacturing process and statistical control/feedback) and output (e.g., setting barriers for waste discharge) [40], meanwhile, organizations are required legally to report their environmental impacts regularly to the relevant government authorities (e.g., disclosing environmental information) [41] When firms are able to meet government requirements through environmental practices, they will gain greater regulatory elasticity or avoid more stringent regulations in the future.

Market pressure has a positive impact on both of SEM and HEM. With the increasing emphasis on environment in the market, the degree of resource consumption, whether the waste is environmentally friendly disposed of, and the price are important criteria for market participants to consider when making purchase decisions [42]. Thus, collecting and disclosing environmental information, and greening product and process is important reaction to the pressure of market to seek competitive advantages and gain eco-friendly brand recognition [17].

Slack resources are found to have a positive impact on both of SEM and HEM, suggesting that firms aiming to gain social legitimacy and competitive advantages by environmental practices are encouraged to achieve abundant resources. This supports Leonidou, Leonidou, Fotiadis and Zeriti [25] and Chen, et al. [43] suggestion that ample slack resources foster firms' adaptability, cushion the uncertainty of external environment, 
specially, it will guarantee the funds and materials of HEM, and help social-oriented SEM with the understanding of external contexts thus allow them to respond in a more timely and effective manner.

Analysis of the relationship between top management's environmental awareness, SEM, and HEM emphasizes the vital role of top management's environmental awareness in fostering EM practices in terms of soft and hard dimensions. It is recommended that top management with strong environmental awareness could attach more attention to the green information in market (e.g., actively collecting green information), response actively to social requirements (e.g., publishing their environmental information to society), and allocate adequate and timely resources to green product design and manufacturing process [7, 28].

This paper defines SEM as social and explicit environmental behaviors. It suggests that SEM is more likely to be affected by external drivers of regulatory pressure and market pressure, and the reasons for this phenomenon may be as follows. On the one hand, government mainly issues a series of environmental laws and regulations to force or induce firms to increase environmental protection efforts to achieve regulatory legitimacy, such as requiring environmental information disclosure, or providing firms with information in the context of which customer demand is vague [44]. On the other hand, stakeholders from market may force firms to comply with environmental ethics and norms through informal methods such as boycott or complaint to make firms assume more environmental responsibility to achieve moral legitimacy [45]. Therefore, relatively short time-consuming methods such as information collection oriented by the market or customers, employee participation and training, and environmental information disclosure are more likely to obtain regulatory and moral legitimacy thus reap the benefits in a short period. However, structural HEM requires firms to pay more attention from internal contexts, for example, green product design needs sufficient talents, green manufacturing process and statistical control/ feedback require advanced technology, equipment and capital support, which requires firms to be equipped with ample resources and top management with environmental awareness so as to make long-term decisions for improving the environment.

\section{Conclusions}

This study categorizes EM into SEM and HEM, and the driving factors of these two dimensions are analyzed. Research hypotheses are proposed based on relevant researches and theoretical analysis, and data is collected from China's manufacturing firms for empirical analysis. The main conclusions include: (1) regulatory pressure, market pressure, slack resources and top management's environmental awareness impose a positive and significant role on both SEM and HEM;
(2) SEM is easily affected by external pressures of government and market, while HEM is more likely to be driven by internal pressures of slack resources and top management's environmental awareness.

The conclusions can provide several guidelines and implications for both academia and practitioners. Theoretically, this study has made new contributions to understanding the heterogeneity and specific drivers of EM practices. EM practices are classified into SEM and HEM and the specific power sources of the two dimensions are explored. It improves the pertinence of extent research, and lays managers' emphasis on specific EM practices and their corresponding drivers.

This study also provides enlightenment for practitioners. First, the Chinese government has promulgated 13 laws and 30 regulations related to ecological environments so far (see Appendix 2), it is suggested that the proper law and regulation should be created if it is not stated in the current law of environmental protection to help firms overcome organizational inertia, and then enable firms to proactively implement environmental practices, moreover, externality should be avoided and the law and regulations should be fully enforced by the responsible authorities. Second, firms have adopted a series of EM practice in different operational dimensions to achieve sustainable development (see Appendix 3), however, establishing more effective environmental funds system, setting up insurance of indemnity, and implementing waste minimization concept also should be taken into their consideration. Third, the Best Practicable Environmental Option (BPEO) should be practiced by both the government and firms in China. Furthermore, it is indicated that the practitioners should convert their mind-set only focusing on external pressures to internal drivers considering the substantial effect of HEM on improving environmental performance [17]. Specially, for regulatory agencies, focusing on top management's environmental awareness and slack resources is good breakthrough point. For example, strengthening effective communication between environmental protection departments and top management is conducive to specify suitable environmental strategic direction for firms. In addition, reducing the burden or providing subsidiary resources for firms is also effective approaches. For firms, cultivating an environmental protection culture and allocating resources reasonably is conductive to implement environmental practices smoothly. On the one hand, several supportive measures such as providing training programs related to environmental protection and involving employees to solve environmental problems can be applied to raise the environmental consciousness within firms. On the other hand, resource priority should be given to product and process phases due to their substantial outputs.

However, the following limitations must be considered to interpret the results of this study. First, a relatively small sample was used due to manual data 
collection. Second, it is also acknowledged that the cross-sectional data used may limit the generalization of findings, as firms at different development stages of EM may be affected by different drivers. Therefore, future studies may collect data in a wider range to strengthen the generalizability. Another suggestion is to use longitudinal data to study the differences in driving factors of environmental management at various lifecycle.

\section{Acknowledgements}

This work was supported by the National Social Science Planning Project of China (No. 20BGL195).

\section{Conflict of Interest}

The authors declare no conflict of interest.

\section{Appendix}

\begin{tabular}{|c|c|}
\hline Variables & Items \\
\hline \multirow{3}{*}{ Regulatory pressure } & $\begin{array}{c}\text { RP1: Our production activities should be in accord with the requirements of national environmental regula- } \\
\text { tions. }\end{array}$ \\
\hline & RP2: Our green production can be subsidized by the government. \\
\hline & RP3: Penalties are imposed by the government for firms' violation of environmental regulations and standards. \\
\hline \multirow{4}{*}{ Market pressure } & $\begin{array}{l}\text { MP1: Financial institutions may not support our firm if our products or emissions release environmentally } \\
\text { hazardous substances. }\end{array}$ \\
\hline & MP2: Our customers often consider environmental factors when making purchase choices. \\
\hline & MP3: Our suppliers' environmental attitude has an impact on our firm’s business. \\
\hline & MP4: Being responsible for the environment is the basic requirement of our industry. \\
\hline \multirow{3}{*}{ Slack resources } & SR1: Our firm is equipped with sufficient physical resources for pro-environmental practices. \\
\hline & SR2: Our firm is equipped with ample financial resources for pro-environmental practices. \\
\hline & SR3: Our firm can always find the "manpower" to implement pro-environmental practices. \\
\hline \multirow{3}{*}{$\begin{array}{c}\text { Top management's } \\
\text { environmental } \\
\text { awareness }\end{array}$} & TMEA1: Our top management can obtain valuable information to improve the environmental performance. \\
\hline & TMEA2: Our top management spends enough time identifying environmental defects in firm's operations. \\
\hline & TMEA3: Our top management allocates enough resources to support firm's environmentally friendly activities. \\
\hline \multirow{7}{*}{$\begin{array}{l}\text { Soft environmental } \\
\text { management }\end{array}$} & SEM1: Adequate training in environmental preservation has been provided to employees. \\
\hline & $\begin{array}{l}\text { SEM2: Adequate training for employees' deeper understanding of firm's environmental policies has been of- } \\
\text { fered. }\end{array}$ \\
\hline & $\begin{array}{c}\text { SEM3: Employees' environmental suggestions are treated as important references to improve environmental } \\
\text { performance. }\end{array}$ \\
\hline & SEM4: Employees involve in and are responsible for the design of environmental management system. \\
\hline & SEM5: Keeping a close relationship to customers in general is of great importance. \\
\hline & SEM6: Customer requirements are taken into account and comprehensively analyzed in our production. \\
\hline & SEM7: We disclose environmental information to the public actively. \\
\hline \multirow{6}{*}{$\begin{array}{l}\text { Hard environmental } \\
\text { management }\end{array}$} & HEM1: Our products are designed to minimize material / energy consumption. \\
\hline & HEM2: Our products are designed with the characteristics of reuse, recycling, and recovery of materials. \\
\hline & HEM3: Employees are provided with available information of raw material consumption and waste discharge. \\
\hline & HEM4: Data of material consumption and waste discharge can be recorded in time. \\
\hline & HEM5: Our production process is green and efficient. \\
\hline & ing process will be stopped immediately for environmental problems. \\
\hline
\end{tabular}


Appendix 2: Current environmental laws and regulations of China.

\begin{tabular}{|c|c|}
\hline Type & Current environmental laws and regulations \\
\hline \multirow{13}{*}{ Laws } & 1. The Law on Environmental Protection \\
\hline & 2. Law of Marine Environmental Protection \\
\hline & 3. Law of Prevention and Control of Water Pollution \\
\hline & 4. The Law on the Prevention and Control of Air Pollution \\
\hline & 5. The Law on Pollution Prevention and Control of Solid Waste \\
\hline & 6. Law of Prevention and Control of Pollution from Environmental Noise \\
\hline & 7. The Cleaner Production Promotion Law \\
\hline & 8. Environment Impact Assessment Law \\
\hline & 9. Radioactive Pollution Prevention and Control Law \\
\hline & 10. Circular Economy Promotion Law \\
\hline & 11. Environmental Protection Tax Law \\
\hline & 12. Nuclear Safety Law \\
\hline & 13. The Law on the Prevention and Control of Soil Pollution \\
\hline \multirow{23}{*}{ Regulations } & $\begin{array}{c}\text { 1.The Regulations of the People's Republic of China Concerning Environmental Protection in Offshore Oil } \\
\text { Exploration and Exploitation }\end{array}$ \\
\hline & 2. Administrative Rules of Waste-dumping to the Ocean of the People's Republic of China \\
\hline & $\begin{array}{l}\text { 3. Regulations of the People's Republic of China on the Administration of Supervision over Safety of Nuclear } \\
\text { Facilities for Civilian Use }\end{array}$ \\
\hline & 4. Regulations of the People's Republic of China on the Management of Nuclear Materials \\
\hline & 5. Regulations on Environmental Management for Preventing Shipbreaking Pollution \\
\hline & $\begin{array}{l}\text { 6. The Regulations Concerning the Prevention and Cure of Pollution Damage of Marine Environment by Pollutants } \\
\text { from Land }\end{array}$ \\
\hline & $\begin{array}{l}\text { 7. Regulations of the People's Republic of China on the Control of Pollution Damage to the Marine Environment in } \\
\text { Coastal Construction Projects }\end{array}$ \\
\hline & 8. Regulations Governing Emergency of Nuclear Accidents of Nuclear Power Plants \\
\hline & 9. Regulations of the People's Republic of China on Natural Reserves \\
\hline & 10. Interim Regulations Concerning the Prevention and Control of Water Pollution of The Huaihe River Valley \\
\hline & 11. Regulations on environmental protection management of construction project \\
\hline & 12. The Regulations of Safety Management on Hazard Chemicals \\
\hline & 13. Regulations for Medical Waste Management \\
\hline & 14. The Measures for the Administration of Permit for Operation of Dangerous Wastes \\
\hline & 15. Regulations on Biosafety Management of Pathogenic Microorganism Laboratory \\
\hline & 16. Regulations on Safety and Protection of Radioisotope and Radiographs \\
\hline & $\begin{array}{l}\text { 17. Regulations on the Prevention and Control of Pollution Damage to the Marine Environment by Marine Engineer- } \\
\text { ing Construction Projects }\end{array}$ \\
\hline & 18. Regulations on the Supervision and Administration of Civil Nuclear Safety Equipment \\
\hline & 19. Regulations on the National Census of Pollution Sources \\
\hline & $\begin{array}{c}\text { 20. Measures of the people's Republic of China for the Examination and Approval of the Entry and Exit of Livestock } \\
\text { and Poultry Genetic Resources and Foreign Cooperative Research and Utilization }\end{array}$ \\
\hline & 21. Regulations on the Administration of the Recovery and Treatment of Waste Electrical and Electronic Products \\
\hline & 22. Regulations on Planning Environmental Impact Assessment \\
\hline & 23. Regulations on the Prevention and Control of Vessel induced Sea Pollution from Marine Environment \\
\hline
\end{tabular}


Appendix 2: Continued.

\begin{tabular}{|c|r|}
\hline \multirow{4}{*}{ Regulations } & 24. Regulations on the Administration of Transport Safety of Radioactive Materials \\
\cline { 2 - 3 } & 25. Regulations on the Administration of Ozone Depleting Substances \\
\cline { 2 - 3 } & 26. Regulations on the Administration of Taihu Lake Basin \\
\cline { 2 - 3 } & 27. Regulations on Safety Management of Radioactive Waste \\
\cline { 2 - 3 } & 28. Regulations on Urban Drainage and Sewage Treatment \\
\cline { 2 - 3 } & 29. Regulations on Prevention and Control of Pollution from Large Scale Livestock and Poultry Breeding \\
\hline
\end{tabular}

Appendix 3: Corporate environmental management practices.

\begin{tabular}{|c|c|}
\hline Dimensions & Corporate environmental management practices \\
\hline \multirow{4}{*}{ Product } & Green product design \\
\hline & Product Life Cycle Assessment (LCA) \\
\hline & Green packaging \\
\hline & Green marketing \\
\hline \multirow{6}{*}{ Manufacturing process } & Inputting environmentally friendly materials \\
\hline & Water resources management \\
\hline & Saving energy and reducing consumption \\
\hline & Recycling \\
\hline & Statistical control/feedback \\
\hline & Using pollution prevention technology \\
\hline \multirow{5}{*}{ Waste disposal } & Exhaust emission and management \\
\hline & Solid waste management \\
\hline & Sewage disposal \\
\hline & Noise management \\
\hline & Greenhouse gas emission management \\
\hline \multirow{2}{*}{ External relationship } & Establishing green alliance \\
\hline & Environmental information disclosure \\
\hline \multirow{4}{*}{ Supply chain management } & Green purchasing \\
\hline & Environmental control of suppliers \\
\hline & Consumer collaboration \\
\hline & Investment recovery \\
\hline \multirow{9}{*}{ Organization and System } & Setting up environmental policy \\
\hline & Establishing environmental protection department or team \\
\hline & Environmental training \\
\hline & Green office and environmental promotion \\
\hline & Employee involvement \\
\hline & Periodic environmental audits \\
\hline & Implementing environmental accounting \\
\hline & Establishing an environmental performance evaluation system \\
\hline & Passed ISO14001 Environmental Management System certification \\
\hline
\end{tabular}




\section{References}

1. CAI W., LI G. The drivers of eco-innovation and its impact on performance: Evidence from China. Journal of Cleaner Production, 176, 110, 2018.

2. DIMAGGiO P., POWELL W. The iron cage revisited: institutional isomorphism and collective rationality in organizational fields. American Sociological Review, 48, 147, 1983.

3. HOJNIK J., RUZZIER M. What drives eco-innovation? A review of an emerging literature. Environmental Innovation and Societal Transitions, 19, 31, 2016.

4. TESTA F., BOIRAL O., IRALDO F. Internalization of environmental practices and institutional complexity: can stakeholders pressures encourage greenwashing? Journal of Business Ethics, 147, 287, 2018.

5. TSAI K., LIAO Y. Innovation capacity and the implementation of eco-innovation: toward a contingency perspective. Business Strategy and the Environment, 26, 1000, 2017.

6. DEMIREL P., KESIDOU E. Sustainability-oriented capabilities for eco-innovation: Meeting the regulatory, technology, and market demands. Business Strategy and the Environment, 28, 847, 2019.

7. JIANG Y., ASANTE D., ZHANG J., CAO M. The effects of environmental factors on low-carbon innovation strategy: A study of the executive environmental leadership in China. Journal of Cleaner Production, 266, 121998, 2020.

8. BERRONE P., FOSFURI A., GELABERT L., GOMEZMEJIA L.R. Necessity as the mother of "green" inventions: institutional pressures and environmental innovations. Strategic Management Journal, 34, 891, 2013.

9. DEL RIO P., ROMERO-JORDAN D., PENASCO C. Analysing firm-specific and type-specific determinants of eco-Innovation. Technological and Economic Development of Economy, 23, 270, 2017.

10. KLASSEN R., MCLAUGHLIN C. The impact of environmental management on firm performance. Management Science, 42, 1199, 1996.

11. MERLI R., PREZIOSI M. The EMAS impasse: factors influencing Italian organizations to withdraw or renew the registration. Journal of Cleaner Production, 172, 4532, 2018.

12. TUNG A., BAIRD K., SCHOCH H. The relationship between organisational factors and the effectiveness of environmental management. Journal of Environmental Management, 144, 186, 2014.

13. MA Y., ZHANG Q., YIN H. Environmental management and labor productivity: the moderating role of quality management. Journal of Environmental Management, 255, 2020.

14. RAHMAN S., BULLOCK P. Soft TQM, hard TQM, and organisational performance relationships: an empirical investigation. Omega-International Journal of Management Science, 33, 73, 2005.

15. TRUMPP C., ENDRIKAT J., ZOPF C., GUENTHER E. Definition, Conceptualization, and Measurement of Corporate Environmental Performance: A Critical Examination of a Multidimensional Construct. Journal of Business Ethics, 126, 185, 2013.

16. FLYNN B.B., SCHROEDER R.G., SAKAKIBARA S. The Impact of quality management practices on performance and competitive advantage. Decision Sciences, 26, 659, 1995.
17. MENG X., ZENG S., XIE X., ZOU H. Beyond symbolic and substantive: strategic disclosure of corporate environmental information in China. Business Strategy and the Environment, 28, 403, 2019.

18. ZHANG Y., WANG J., XUE Y., YANG J. Impact of environmental regulations on green technological innovative behavior: An empirical study in China. Journal of Cleaner Production, 188, 763, 2018.

19. CAMPBELL J.L. Why would corporations behave in socially responsible ways? An institutional theory of corporate social responsibility. Academy of Management Review, 32, 946, 2007.

20. LI Y. Environmental innovation practices and performance: moderating effect of resource commitment. Journal of Cleaner Production, 66, 450, 2014.

21. LIAO Y.-C., TSAI K.-H. Innovation intensity, creativity enhancement, and eco-innovation strategy: The roles of customer demand and environmental regulation. Business Strategy and the Environment, 28, 316, 2019.

22. HUANG X., HU Z., LIU C., YU D., YU L. The relationships between regulatory and customer pressure, green organizational responses, and green innovation performance. Journal of Cleaner Production, 112, 3423, 2016.

23. WANG S., LI J., ZHAO D. Institutional pressures and environmental management practices: the moderating effects of environmental commitment and resource availability. Business Strategy and the Environment, 27, 52, 2017.

24. BOURGEOIS L.J. On the measurement of organizational slack. Academy of Management Review, 6, 29, 1981.

25. LEONIDOU L.C., LEONIDOU C.N., FOTIADIS T.A., ZERITI A. Resources and capabilities as drivers of hotel environmental marketing strategy: implications for competitive advantage and performance. Tourism Management, 35, 64, 2013.

26. GARAY L., FONT X. Doing good to do well? Corporate social responsibility reasons, practices and impacts in small and medium accommodation enterprises. International Journal of Hospitality Management, 31, 329, 2012.

27. HAMBRICK D.C. Upper echelons theory: an update. Academy of Management Review, 22, 334, 2007.

28. ZHANG B., WANG Z., LAI K.-H. Mediating effect of managers' environmental concern: Bridge between external pressures and firms' practices of energy conservation in China. Journal of Environmental Psychology, 43, 203, 2015.

29. GARCÍA-SÁNCHEZ I.M., MARTÍNEZ-FERRERO J. Chief executive officer ability, corporate social responsibility, and financial performance: The moderating role of the environment. Business Strategy and the Environment, 28, 542, 2018.

30. LU Y., ABEYSEKERA I. Stakeholders' power, corporate characteristics, and social and environmental disclosure: evidence from China. Journal of Cleaner Production, 64, 426, 2014.

31. CHOO A.S., LINDERMAN K.W., SCHROEDER R.G. Method and psychological effects on learning behaviors and knowledge creation in quality improvement projects. Management Science, 53, 437, 2007.

32. REN S., HE D., ZHANG T., CHEN X. Symbolic reactions or substantive pro-environmental behaviour? An empirical study of corporate environmental performance under the government's environmental subsidy scheme. Business Strategy and the Environment, 28, 1148-116, 2019. 
33. SHU C., ZHOU K.Z., XIAO Y., GAO S. How green management influences product innovation in China: the role of institutional benefits. Journal of Business Ethics, 133, 471, 2014.

34. YANG D., WANG A.X., ZHOU K.Z., JIANG W. Environmental strategy, institutional force, and innovation capability: a managerial cognition perspective. Journal of Business Ethics, 159, 1147, 2018.

35. TANG Z., TANG J. Stakeholder-firm power difference, stakeholders' CSR orientation, and SMEs' environmental performance in China. Journal of Business Venturing, 27, 436, 2012.

36. EIADATA Y., KELLYA A., ROCHEA F., EYADATB H. Green and competitive? An empirical test of the mediating role of environmental innovation strategy. Journal of World Business, 43, 131, 2008.

37. ZHU Q., SARKIS J. Relationships between operational practices and performance among early adopters of green supply chain management practices in Chinese manufacturing enterprises. Journal of Operations Management, 22, 265, 2004.

38. FLYNN B.B., SAKAKIBARA S., SCHROEDER R.G., BATES K.A., FLYNN E.J. Empirical research methods in operations management. Journal of Operations Management, 9, 250, 1990.

39. HAIR J.F., BLACK W.C., BABIN B.J., ANDERSON R.E. Multivariate data analysis. Prentice-Hall: Upper Saddle River, NJ, 2010.
40. WANG R., WIJEN F., HEUGENS P.P.M.A.R. Government's green grip: multifaceted state influence on corporate environmental actions in China. Strategic Management Journal, 39, 403, 2018.

41. ASIRI N., KHAN T., KEND M. Environmental management accounting in the Middle East and North Africa region: Significance of resource slack and coercive isomorphism. Journal of Cleaner Production, 267, 2020.

42. LIN R.J., TAN K.H., GENG Y. Market demand, green product innovation, and firm performance: evidence from Vietnam motorcycle industry. Journal of Cleaner Production, 40, 101, 2013.

43. CHEN X., YI N., ZHANG L., LI D. Does institutional pressure foster corporate green innovation? Evidence from China's top 100 companies. Journal of Cleaner Production, 188, 304, 2018.

44. STUCKI T., WOERTER M., ARVANITIS S., PENEDER M., RAMMER C. How different policy instruments affect green product innovation: A differentiated perspective. Energy Policy, 114, 245, 2018.

45. PHAN T.N., BAIRD K. The comprehensiveness of environmental management systems: The influence of institutional pressures and the impact on environmental performance. Journal of Environmental Management, 160, 45, 2015. 